\title{
Borehole logging based on ultrasonic measurements
}

\author{
Vitalii Tron $^{1 *}$, Alena Haponenko ${ }^{2}$, Iryna Haponenko ${ }^{2}$, and Dmytro Paranyuk ${ }^{3}$ \\ ${ }^{1}$ Kryvyi Rih National University, Department of Automation, Computer Science and Technology, \\ 11 Matusevycha St., 50027 Kryvyi Rih, Ukraine \\ ${ }^{2}$ Kryvyi Rih National University, Research Department, 11 Matusevycha St., 50027 Kryvyi Rih, \\ Ukraine \\ ${ }^{3}$ PJSC “ArcelorMittal Kryvyi Rih", Department of Security, 1 Kryvorizhstali St., 50000 Kryvyi Rih, \\ Ukraine
}

\begin{abstract}
The coefficient of ultrasound attenuation is noted for sufficient sensitivity to provide high-quality characteristics of rocks. Efficiency of transforming electromagnetic signals into elastic oscillations of the ferromagnetic rock and backward depends on magnetic permeability of the rock, i.e. the content of the ferromagnetic component. The suggested method enables receiving additional data on concentration and structure of the ferromagnetic component distributed in the rock. To use the method one does not need either borehole liquid or any specific devices to introduce elastic oscillations into the rock, this fact facilitating its extensive application.
\end{abstract}

\section{Introduction}

There are over 80 prospected iron ore deposits in Ukraine. Its basic reserves $-70 \%$ in total and $80 \%$ mined - are concentrated in Kryvyi Rih iron ore basin with about 90 enterprises of ferrous metallurgy industries [1].

Commercial reserves of the country make up over $30 \mathrm{bln} \mathrm{t}$ of iron ore ensuring the functioning of enterprises for about 95-100 years ahead. Seven of ten largest iron ore enterprises of Ukraine are situated in Kryvyi Rih region - the PrJSC "Inhuletskyi GZK", the PJSC "SOUTHERN MINING FACTORY", the mining department of the PJSC "ArcellorMittal Kryvyi Rih", the PJSC "Centralnyi GZK", the PJSC "Pivnichnyi GZK", the PJSC "Kryvbaszalizrudkom" and the PJSC "Sukha Balka". These enterprises of Kryvyi Rih iron ore basin meet over $90 \%$ of Ukrainian metallurgical needs in raw materials [ $1-5]$.

In general, iron ores occur in three basic types [1, 6-9] - rich martite, ferruginous quartzite and brown iron clay. Ferruginous quartzite, which is the main raw material reserve of Kryvyi Rih iron ore basin, refers to the Sklevatskyi geological-industrial type. Depending on availability of bands, magnetite ferruginous quartzites are divided into several types of various technological value. These includes magnetite quartzites with almost no silicates and carbonates; silicate-magnetite quartzites with the subordinate number of silicate bands; hematite-mica-magnetite quartzites with the subordinate number

\footnotetext{
*Corresponding author: vtron@ukr.net
} 
of hematite bands; magnetite-silicate quartzites with the subordinate number of magnetite bands; poor quartzites on the boundary of industrial value; carbonate-magnetite quartzites; silicate-carbonate or carbonate-silicate magnetite quartzites.

In some mineral deposits (coal, some construction rocks), qualitative characteristics change within either pit boundaries or large blocks slightly, this fact enabling mining ores of homogenous composition. In most cases, quality indices vary greatly within deposits $[1,2,6-9]$. In such deposits, sampling is conducted both during exploration and mining stages to detect and clarify deposit boundaries, determine the character of mineral types distributing within the massif and their qualitative characteristics as well as to control changes in quality of useful minerals engaged in technological processes [11-13], identify mathematical models of technological processes, and synthesize optimal, adaptive and robust control [16 - 18].

In general, industrial boundaries of useful minerals including their division into types and their separate blocks are distinguished by drilling exploratory boreholes followed by sludge or kern sampling, blasthole sludge sampling, trench-channel sampling or that by using various geophysical means [10 - 13].

Mechanical drilling speed is a quite dynamic indicator characterizing rock properties [19]. The disadvantage of this approach is its insufficiency in complicated geological structures of iron ore deposits, that requiring analysis of more data to confirm research results [20,21].

Determination of the rock type in drilling by means of two indices - mechanical drilling speed and torque suggested in [20]. There is a disadvantage of this approach implying that required accuracy of rock type recognition is possible under the binary geological structure as indicated parameters accurately point out homogenous character and hardness of the rock. In case of several mineralogical and technological types, application of this approach can be complicated.

In [22], to monitor drilling, the following parameters are used: horizontal and vertical vibrations, axis pressure, torque, drilling speed, rotation, etc. The disadvantage of this method can involve controlled parameters among which only those of the drilling rig are available, while direct or indirect measurements of rock characteristics are ignored. A similar approach is used in [23] to recognize the ternary geological structure that includes three rock types drilled. Yet, as in the previous work, recognition of the rock types is mostly performed through a single indicator (hardness) and parameters of a drilling rig without measuring characteristics of the rock itself.

The mutual disadvantage of the considered sampling methods is reduction of data authenticity because of division of operations into sampling and analysis, huge labour intensity and absence of operational efficiency. The most efficient solution of the problem is logging - complete recording of data collected during drilling by applying geophysical methods. The data allow creating a complete picture of a geological section covered by a given borehole.

\section{Methods}

Logging is performed by electric, magnetic, nuclear-physical, thermal, ultrasonic and other methods [24-27]. While conducting them, along the borehole shaft by means of geophysical sensors lowered on the cable, there are some values measured depending on a single or several physical properties of rocks crosscut by the borehole. Sensor signals are transmitted to the surface and recorded by mobile surface devices in an analog or digital form [28 - 32].

Ultrasonic logging is based on studying velocity and attenuation of elastic waves in rocks. Velocities of elastic wave propagation in rocks vary in a wide range and depend on 
physical properties, structure, texture, condition and other internal and external factors [33-35]. Propagation velocity of longitudinal waves in hard rocks varies mainly from 1500 to $7000 \mathrm{~m} / \mathrm{sec}$, that of transverse waves - from 800 to $5000 \mathrm{~m} / \mathrm{sec}[25,26]$.

The ratio of propagation velocities of longitudinal and transverse waves in different rocks varies within a wide range [25]. In case of igneous and metamorphic rocks, it usually makes $C_{p} / C_{s}=1.7 / 1.9$. When full water saturation occurs, this ratio $C_{p} / C_{s}$ slightly increases. Sedimentary rocks have this ratio changed from 1.5 to 2.0 and more.

Generalized results of investigating into rocks under atmospheric pressure are presented in [36]. Basic experimental data are given in Table 1 that indicate great changes in propagation velocity of longitudinal and transverse waves in rocks in spite of a small difference in their density.

Table 1. Velocities of the longitudinal $\left(c_{l}\right)$ and transverse $\left(c_{t}\right)$ ultrasonic waves, density, elasticity modules $E$ and $\mu$, the Poisson coefficient $\sigma$ for some rocks.

\begin{tabular}{|l|c|c|c|c|c|c|}
\hline \multicolumn{1}{|c|}{ Medium } & $c_{l}, \mathrm{~m} / \mathrm{sec}$ & $c_{t}, \mathrm{~m} / \mathrm{sec}$ & $p, \mathrm{~g} / \mathrm{cm}^{3}$ & $E, \mathrm{~kg} / \mathrm{mm}^{2}$ & $\mu, \mathrm{kg} / \mathrm{mm}^{2}$ & $\sigma$ \\
\hline Marble & 6150 & 3260 & 2.66 & 7360 & 2820 & 0.305 \\
\hline Mica & 7760 & 2160 & 2.81 & 3820 & 1310 & 0.458 \\
\hline Granite & 4450 & 2780 & 2.62 & 4870 & 2060 & 0.18 \\
\hline Basalt & 5930 & 3140 & 2.72 & 6990 & 2680 & 0.306 \\
\hline Diabase & 4970 & - & 2.79 & 7010 & - & - \\
\hline Syenite 31 & 5050 & 3020 & 2.72 & 6170 & 2550 & 0.22 \\
\hline Dolomite 9 & 4450 & 2870 & 2.52 & 4990 & 2110 & 0.18 \\
\hline Labradonite 44 & 5450 & 3370 & 2.68 & 7390 & 3110 & 0.19 \\
\hline Diorite 39 & 6130 & 3140 & 2.91 & 7720 & 2930 & 0.32 \\
\hline Gabbro 38 & 6320 & 3330 & 2.96 & 8770 & 3340 & 0.31 \\
\hline Gypsum & 4790 & 2370 & 2.26 & 3600 & 1270 & 0.338 \\
\hline Gneiss & 7870 & 3010 & 2.66 & 6810 & 2410 & 0.414 \\
\hline Anhydrite & 4900 & - & 2.93 & 7450 & - & - \\
\hline Limestone & 6130 & 3200 & 2.70 & 7240 & 2760 & 0.313 \\
\hline
\end{tabular}

Unlike propagation velocity of elastic waves, physical dispersion of which is absent in most rocks, the attenuation coefficient is determined by frequency of elastic oscillation [36, 37]. In a wide range of frequencies - from $1 \mathrm{~Hz}$ to $10 \mathrm{MHz}$ - the attenuation coefficient in different rocks varies from $1 \cdot 10^{-8}$ to $2 \cdot 10^{2} \mathrm{~m}^{-1}$. The attenuation decrement in the same range of frequencies changes from $1 \cdot 10^{-2}$ to 1.0 on average. The attenuation coefficient increases with the rise of frequency. Yet, there is no clearly expressed unambiguous functional dependency of ultrasound attenuation on frequency for rocks.

The attenuation coefficient of transverse waves in crystalline rocks is usually equal to the attenuation coefficient of longitudinal waves or about 1.5-2 times larger [36]. Wet clays and water-saturated sand have a considerable difference in attenuation coefficients of transverse and longitudinal waves (up to 5 and higher). If velocities of longitudinal and transverse waves in rocks are greater, attenuation coefficients of these wave types are on the contrary smaller. It should be noted that if propagation velocities of elastic waves in most solid monolithic rocks vary by just $40-60 \%$, their attenuation coefficients are $2-4$ times larger $[25,26]$. This circumstance indicates the fact that the attenuation coefficient of elastic waves is a more sensitive parameter for high-quality characteristic of rocks than ultrasound velocity. Yet, here it should be taken into account that ultrasound attenuation is affected by many disturbing factors.

To stimulate elastic oscillations in ferromagnetic rocks of the massif, we suggest using the acoustic transducer of the electromagnetic type [37]. It is a distributed structure (Fig. 1) comprising a constant magnetic field source, sources of alternating magnetic field, some 
amount of the ferromagnetic component of the rock where some transformation of the electromagnetic field energy into that of elastic oscillations of medium particles occurs.

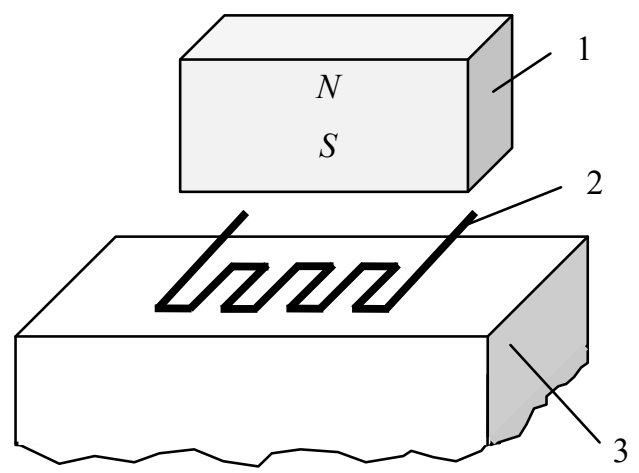

Fig. 1. The acoustic transducer of the electromagnetic type: 1 - the constant magnetic field source; 2 - alternating magnetic field sources; 3 - the rock with the ferromagnetic component.

With elastic waves excited, the electromagnetic transducer transforms electromagnetic signals into elastic oscillations of the ferromagnetic rock due to the magnitostrictive effect and the ponderomotive action of the electromagnetic field. In some point of the ferromagnetic with coordinates $x_{k}$, the constant magnetic field of $H^{0}\left(x_{k}\right)$ intensity and the alternating one are formed (under the action of the electromagnetic impulse of a certain amplitude, duration and frequency) with $H^{*}\left(x_{k}, t\right)$ intensity at $t$ moment. Deformations are formed in magnetic fields $H^{*}\left(x_{k}, t\right)$ and $H^{0}\left(x_{k}\right)$ in the ferromagnetic. The energy passes further by elastic waves in the area of deformation formation. The acoustic transducer of the electromagnetic types forms elastic waves directly in the area of measuring characteristics of ferromagnetic rocks in the massive. As there are no other intermediate elements to deliver formed elastic waves into the medium, there are no errors of measuring its characteristics conditioned by these factors.

The transformation chain of electromagnetic waves into elastic oscillations of the ferromagnetic rock looks as follows [38]:

$$
\left\{\begin{array}{l}
u\left(x_{m}, t\right)=F_{u}\left(\vec{H}^{*}\left(x_{k}, t\right) \otimes \vec{H}^{0}\left(x_{k}\right) \mid c_{i j k l}^{H}, \rho_{0}, r_{n m}, m_{p q k l}, \mu_{r s}^{\varepsilon}\right) ; \\
\vec{H}^{*}\left(x_{k}, t\right)=F_{H}\left(I^{*}(t)\right) ; \\
I^{*}(t)=F_{I}\left(U_{i n}(t)\right),
\end{array}\right.
$$

where $U_{\text {in }}(t)$ is the difference of electric potentials at the electric input (on the terminals of the electric contour) of the ultrasonic electromagnetic transducer; $I^{*}(t)$ is the electric current changing with time ( $t$ symbol) in the electric contour of the transducer; $\vec{H}^{*}\left(x_{k}, t\right)$ is the intensity vector of the alternating magnetic field formed by the electric field of the ultrasonic transducer in the point with coordinates $x_{k}$ in the physical coordinate system; $\vec{H}^{0}\left(x_{k}\right)$ is the intensity vector of the constant bias field that determines the structure of piezomagnetic constants and the character of the stress-strain state of metal in the close proximity to the point with coordinates $x_{k} ; c_{i j k l}^{H}, \rho_{0}, r_{n m}, m_{p q k l}, \mu_{r s}^{\varepsilon}$ are physical and mechanical constants of metal in the domain of alternating and constant magnetic fields : 
$c_{i j k l}^{H}$ is the tensor component of elasticity modules, determined experimentally under the constant intensive magnetic field; $\mu_{r s}^{\varepsilon}$ is the tensor component of magnetic permeability determined experimentally under constant deformations at the assigned intensity of the bias field. Under reception of ultrasonic waves propagating in the ferromagnetic polarized by the constant magnetic field $\vec{H}^{0}\left(x_{k}\right)$, the following transformation chain [38] occurs:

$$
\left\{\begin{array}{l}
U_{\text {out }}(t)=F_{U}(\Phi(t)) ; \\
\Phi(t)=F_{\Phi}\left(\vec{M}\left(x_{k}, t\right)\right) ; \\
\vec{M}\left(x_{k}, t\right)=F_{M}\left(\varepsilon_{i j}\left(x_{k}, t\right) \otimes \vec{H}^{0}\left(x_{k}\right) \mid c_{i j k l}^{H}, \rho_{0}, r_{n m}, m_{p q k l}, \mu_{r s}^{\varepsilon}\right) ; \\
\varepsilon_{i j}\left(x_{k}, t\right)=F_{\varepsilon}\left(\vec{u}\left(x_{k}, t\right)\right),
\end{array}\right.
$$

where $\vec{u}\left(x_{k}, t\right)$ is amplitude values of the translation vector of material particles of the deformed metal, $\vec{M}\left(x_{k}, t\right)$ is dynamic magnetism of the ferromagnetic, $\Phi(t)$ is displacement flux through the electric contour of the alternating magnetic field receiver, $U_{\text {out }}(t)$ is the difference of electric potentials at the output of the alternating magnetic field receiver.

Efficiency of transforming electromagnetic signals into elastic oscillations of the ferromagnetic rock and backward depends on magnetic susceptibility of $\chi$ ore, i.e. on the content of the ferromagnetic component.

Experimental dependency of specific magnetic susceptibility of $\chi$ ore on external magnetism of the field $H$ is provided in Fig. 2.

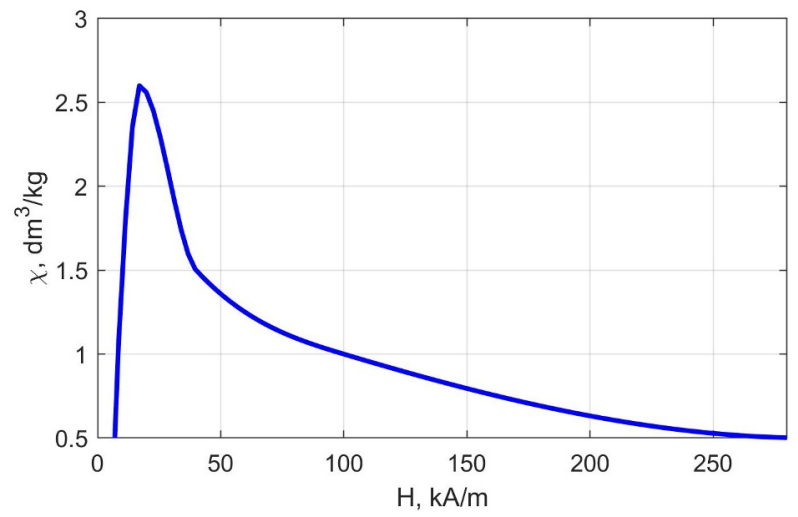

Fig. 2. Dependency of specific magnetic susceptibility of $\chi$ ore on external magnetism of the field $H$.

This dependency is obtained when testing ferruginous quartzites of Kryvyi Rih iron ore basin in the industrial laboratory of online control over mineral quality headed by A.A. Azarian in Kryvyi Rih National University.

\section{Results and discussion}

While conducting experimental investigations, the following parameters of drilling are used as input variables - two inputs: drilling speed and torque; three inputs: drilling speed, torque, specific destruction power; five inputs: drilling speed, torque, specific destruction 
power, horizontzl and vertical vibrations; seven inputs: drilling speed, torque, specific destruction power, horizontal and vertical vibrations, deviation of drilling speed, deviation of axis load; eight inputs: drilling speed, torque, specific destruction power, horizontzl and vertical vibrations, deviation of drilling speed, deviation of axis load, results of ultrasonic measurements.

Table 2 contains measurement results of density of five ore types mined and processed at one of the deposits of Kryvyi Rih iron ore basin. The following symbols of ore types [39] are accepted: 1 - magnetite hornfels; 2 - silicate-carbonate-magnetite hornfels; 3 - redbanded magnetite and hematite-magnetite hornfels; 4 - semioxidized and oxidized hornfels; 5 - silicate shists, barren hornfels and quartz.

Distribution of mineral components in ore types is presented in Fig. 2.
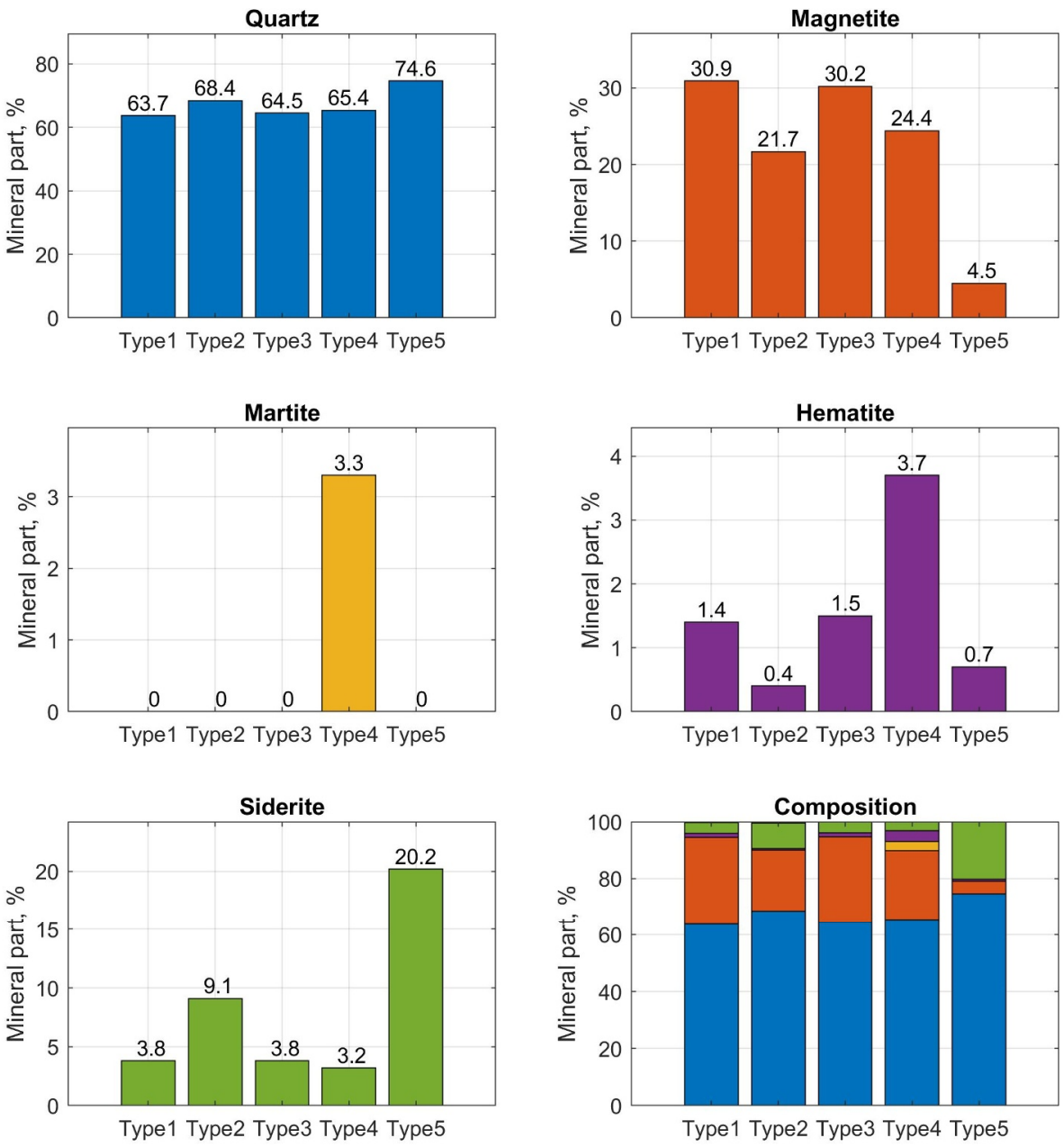

Fig. 3. Mineral composition of ore types.

The velocity of propagating longitudinal ultrasonic waves in the given samples makes $4600-6000 \mathrm{~m} / \mathrm{sec}$, that of transverse waves $-2830-3810 \mathrm{~m} / \mathrm{sec}$, the velocity ratio is $c_{p} / c_{s}=1.75$. This dependency is an averaged characteristic of content and structure of distributing the ferromagnetic component in the rock, physical and mechanical characteristics and condition of the rock massif, i.e. its mineralogical composition. In order 
to identify the mineralogical type of the ferromagnetic rock under study on the basis of obtained measurement results, the measurements of other parameters mentioned above are used.

The obtained results are compared to similar measurements in reference samples. When identifying five ore types with the various number of input parameters, the following values of accuracy indices are obtained: for two inputs $-55 \%$, for three inputs $-68 \%$, for five inputs $-77 \%$, for 7 inputs $-83 \%$, for 8 inputs $-91 \%$. Thus, to identify five ore types in the rock, it is reasonable to consider eight input signals, this enabling accuracy of recognizing $91 \%$ of ore types.

\section{Conclusions}

Ultrasonic logging is based on investigating into parameters of acoustic waves propagating in monolithic rocks including their velocity and attenuation rate. The velocity of ultrasonic wave propagation is measured in a wide range and depends on physical properties, structure, texture, condition and other internal and external factors. In spite of a comparatively small difference in density of rock types, velocity of wave propagation varies within a wide range. Yet, the coefficient of wave attenuation is a far more sensitive parameter for high-quality characteristic of rocks. Besides, the coefficient of ultrasound attenuation is affected by a great many number of disturbing factors.

Efficiency of transforming electromagnetic signals into elastic oscillations of the ferromagnetic rock and backward is dependent on magnetic permeability of ore, i.e. the content of the ferromagnetic component. Thus, the suggested method enables obtainment of additional data on concentration and structure of distributing the ferromagnetic component in the rock. To use it, one does not need any boring liquid or specific devices to introduce elastic oscillations into the rock massif, this fact facilitating its wide application.

During experimental investigations into identification of ferromagnetic rock types, drilling parameters including ultrasonic measurements are used as input variables. The number of considered parameters varies from 2 to 8 . When identifying five ore types, auxiliary application of ultrasonic logging allows increasing accuracy of recognition of ore types from 83 to $91 \%$.

The authors express their sincere gratitude to the Kryvyi Rih National University for support in conducting the research.

\section{References}

1. Azarian, V.A. (2019). Tekhnoloho-teoretychni zasady upravlinnia iakistiu zalizovmisnoi syrovyny heneralizovanoho kompleksu rudopotokiv hirnycho-zbahachuvalnykh kombinativ. $\mathrm{PhD}$ Thesis. Kryvyi Rih, Ukraine: KNU.

2. Stupnik, M.I., Kalinichenko, V.O., Pysmennyi, S.V., \& Kalinichenko, O.V. (2018). Determining the qualitative composition of the equivalent material for simulation of Kryvyi Rih iron ore basin rocks. Naukovyi Visnyk Natsionalnoho Hirnychoho Universytetu, (4), 21-27. https://doi.org/10.29202/nvngu/2018-4/4

3. Kupin, A., Kuznetsov, D., Muzyka, I., Paraniuk, D., Serdiuk, O., Suvorov, O., \& Dvornikov, V. (2018). The concept of a modular cyberphysical system for the early diagnosis of energy equipment. Eastern-European Journal of Enterprise Technologies, 4(2(94)), 71-79. https://doi.org/10.15587/1729-4061.2018.139644

4. Morkun, V., Semerikov, S., Hryshchenko, S., \& Slovak, K. (2017). Environmental geoinformation technologies as a tool of pre-service mining engineer's training for sustainable development of mining industry. CEUR Workshop Proceedings, (1844), 303-310. 
5. Kalinichenko, V., Pysmennyi, S., Shvaher, N., \& Kalinichenko, O. (2018). Selective underground mining of complex structured ore bodies of Kryvyi Rih Iron Ore Basin. E3S Web of Conferences, (60), 00041. https://doi.org/10.1051/e3sconf/20186000041

6. Morkun, V., \& Tron, V. (2014). Automation of iron ore raw materials beneficiation with the operational recognition of its varieties in process streams. Metallurgical and Mining Industry, (6), 4-7.

7. Abdyldaev, K.K., Kuvakov, S.Z., \& Kurmanbek, U.T. (2017). Issledovanie fizikomekhanicheskikh svoystv na razlichnykh glubinakh i anizatropii gornykh porod mestorozhdeniya Makmal. Gornaya Promyshlennost, 1(131), 93-94.

8. Morkun, V., \& Tcvirkun, S. (2014). Investigation of methods of fuzzy clustering for determining ore types, Metallurgical and Mining Industry, (5), 11-14.

9. Morkun, V., Tron, V., \& Goncharov, S. (2015). Automation of the ore varieties recognition process in the technological process streams based on the dynamic effects of high-energy ultrasound. Metallurgical and Mining Industry, (2), 31-34.

10. Golik, V., Komashchenko, V., Morkun, V., \& Irina, G. (2015). Improving the effectiveness of explosive breaking on the bade of new methods of borehole charges initiation in quarries. Metallurgical and Mining Industry, 7(7), 383-387.

11. Golik, V., Komashchenko, V., \& Morkun, V. (2015). Feasibility of using the mill tailings for preparation of self-hardening mixtures. Metallurgical and Mining Industry, (3), 38-41.

12. Golik, V., Komashchenko, V., Morkun, V., \& Burdzieva, O. (2015). Metal deposits combined development experience. Metallurgical and Mining Industry, (6), 591-594.

13. Golik V., Komashchenko V., Morkun V., \& Zaalishvili V. (2015). Enhancement of lost ore production efficiency by usage of canopies. Metallurgical and Mining Industry, (4), 325-329.

14. Morkun, V., Morkun, N., \& Tron, V. (2015). Identification of control systems for ore-processing industry aggregates based on nonparametric kernel estimators. Metallurgical and Mining Industry, (1), 14-17.

15. Bublikov, A., \& Tkachov, V. (2019). Automation of the control process of the mining machines based on fuzzy logic. Naukovyi Visnyk Natsionalnoho Hirnychoho Universytetu, (3), 112-118. https://doi.org/10.29202/nvngu/2019-3/19

16. Morkun, V., \& Tron, V. (2014). Ecological and economic optimization of iron ore processing automated control. Metallurgical and Mining Industry, (5), 8-10.

17. Morkun, V., Morkun, N., \& Pikilnyak, A. (2015). Adaptive control system of ore beneficiation process based on Kaczmarz projection algorithm. Metallurgical and Mining Industry, (2), 35-38.

18. Morkun, V., Morkun, N., \& Tron, V. (2015). Formalization and frequency analysis of robust control of ore beneficiation technological processes under parametric uncertainty. Metallurgical and Mining Industry, (5), 7-11.

19. Yue, Z.Q., Lee, C.F., Law, K.T., \& Lam, L.G. (2015). Automatic monitoring of rotary percussive drilling for ground characterization. International Journal of Rock Mechanics \& Mining Sciences, 41(4), 573-612. https://doi.org/10.1016/j.ijrmms.2003.12.151

20. Schunnesson, H. (2014). Rock characterisation using percussive drilling. International Journal of Rock Mechanics \& Mining Sciences, 35(6). 711-725. https://doi.org/10.1016/s01489062(97)00332-x

21. Schunnesson, H., \& Holme, K. (2015). Drill monitoring for geological mine planning in the Viscaria copper mine, Sweden. CIM Bulletin, 90(1030), 82-89.

22. Beattie, N. (2012). Monitoring-while-drilling for open-pit mining in a hard rock environment. PhD Thesis. Ontario, Canada: Queen's University Kingston.

23. Martin, J. (2013). Application of pattern recognition techniques to monitoring-while-drilling on a rotary electric blast hole drill at an open-pit coal mine. $\mathrm{PhD}$ Thesis. Ontario, Canada: Queen's University Kingston.

24. Karotazh skvazhiny. Retrieved from https://neftegaz.ru/tech-library/geologorazvedka-igeologorazvedochnoe-oborudovanie/147534-karotazh-skvazhiny/ 
25. Akusticheskie svoystva gornykh porod. Retrieved from http://ctcmetar.ru/volnovyeprocessy/9297-akusticheskie-svoystva-gornyh-porod.html

26. Akusticheskiy karotazh po skorosti. Retrieved from http://fccland.ru/dobycha-nefti/6826akusticheskiy-karotazh-po-skorosti.html

27. Morkun, V., Morkun, N., \& Pikilnyak, A. (2015). The study of volume ultrasonic waves propagation in the gas-containing iron ore pulp. Ultrasonics, (56), 340-343. https://doi.org/10.1016/j.ultras.2014.08.022

28. Morkun, V., Morkun, N., \& Pikilnyak, A. (2014). Ultrasonic facilities for the ground materials characteristics control. Metallurgical and Mining Industry, (2), 31-35.

29. Morkun, V., Morkun, N., \& Pikilnyak, A. (2014). Simulation of high-energy ultrasound propagation in heterogeneous medium using k-space method. Metallurgical and Mining Industry, (3), 23-27.

30. Azaryan, A., Gritsenko, A., Trachuk, A., Serebrenikov, V., \& Shvets, D. (2019). Using the intensity of absorbed gamma radiation to control the content of iron in ore. Eastern-European Journal of Enterprise Technologies, 3(5(99)), 29-35. https://doi.org/10.15587/1729$\underline{4061.2019 .170341}$

31. Azaryan, A., Gritsenko, A., Trachuk, A., \& Shvets, D. (2018). Development of the method to operatively control quality of iron ore raw materials at open and underground extraction. EasternEuropean Journal of Enterprise Technologies, 5(5(95)). 13-19. https://doi.org/10.15587/1729$\underline{4061.2018 .144003}$

32. Azaryan, A.A., Batareyev, A.S., Karamanits, F I., Kolosov, V.A., \& Morkun, V.S. (2018). Ways to reduce ore losses and dilution in iron ore underground mining in Kryvbass. Science and Innovation, 14(4), 17-24. https://doi.org/10.15407/scine14.03.017

33. Morkun, V., Morkun, N., \& Pikilnyak, A. (2014). Ultrasonic phased array parameters determination for the gas bubble size distribution control formation in the iron ore flotation. Metallurgical and Mining Industry, (3), 28-31.

34. Morkun, V., Morkun, N., \& Pikilnyak, A. (2014). Simulation of the Lamb waves propagation on the plate which contacts with gas containing iron ore pulp in Waveform Revealer toolbox. Metallurgical and Mining Industry, (5), 16-19.

35. Morkun, V., Morkun, N., \& Pikilnyak, A. (2014). The gas bubble size distribution control formation in the flotation process. Metallurgical and Mining Industry, (4), 42-45.

36. Brazhnikov, N.I. (1965). Ul'trazvukovye metody. Moskva-Leningrad: Energiya.

37. Xie, Y., Rodriguez, S., Zhang, W., Liu, Z., \& Yin, W. (2016). Simulation of an electromagnetic acoustic transducer array by using analytical method and FDTD. Journal of Sensor, 2016, 1-10. https://doi.org/10.1155/2016/5451821

38. Romanyuk, M.I. (2015). Teoreticheskie osnovy rascheta ul'trazvukovykh traktov ustroystv kontrolya poverkhnosti metalloprokata. PhD Thesis. Kyiv, Ukraine: KPI.

39. Kozin, V.Z. (2008). Issledovanie rud na obogatimost'. Ekaterinburg: Ural'skiy gosudarstvennyy gornyy universitet. 